\title{
CULTURE AND THE COGNITIVE SCIENCE OF RELIGION
}

James Cresswell

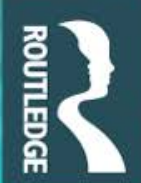




\section{Culture and the Cognitive Science of Religion}

Culture and the Cognitive Science of Religion is the first book to bring together cultural psychology and the cognitive science of religion (CSR). Containing much-needed discussion of how good research should do more than simply follow methodological prescriptions, this thought-provoking and original book outlines the ways in which CSR can be used to study everyday religious belief without sacrificing psychological science.

Cresswell's pragmatist approach expands CSR in a radically new direction. The author shows how language and culture can be integrated within CSR in order to achieve an alternative ontogenetic and phylogenetic approach to cognition and argues that a view of cognition that is not based on modularity, but on the dynamic connection between an organism and its milieu, can lead to a view of evolution that makes much more room for the constitutive role of culture in cognition.

As a provocative attempt to persuade researchers to engage with religious communities more directly, the book should be essential reading for academics, researchers and postgraduate students, as well as psychologists interested in the cognitive science of religion, theological anthropology, religious studies and cultural anthropology.

James (Jim) Cresswell is an associate professor and program chair in psychology at Ambrose University (Calgary, Canada). 
The series Cultural Dynamics of Social Representation is dedicated to bringing the scholarly reader new ways of representing human lives in the contemporary social sciences. It is a part of a new direction - cultural psychology - that has emerged at the intersection of developmental, dynamic and social psychologies, anthropology, education, and sociology. It aims to provide cutting-edge examinations of global social processes, which for every country are becoming increasingly multi-cultural; the world is becoming one 'global village', with the corresponding need to know how different parts of that 'village' function. Therefore, social sciences need new ways of considering how to study human lives in their globalizing contexts. The focus of this series is the social representation of people, communities, and - last but not least - the social sciences themselves.

For more information about this series, please visit www.routledge.com.

\section{In this series}

\section{Optimizing the Self}

Social Representations of Self-help

Ole Jacob Madsen

Imagination in Human and Cultural Development

Tania Zittoun and Alex Gillespie

\section{Representing Development}

Pasts, Presents and Futures of Transformative Models

Edited by David Carré, Jaan Valsiner and Stefan Hampl

\section{Persons and their Minds}

Towards an Integrative Theory of the Mediated Mind Svend Brinkmann

\section{Culture and the Cognitive Science of Religion} James Cresswell 


\title{
Culture and the Cognitive Science of Religion
}

James Cresswell

\author{
Routledge \\ 量 Taylor \& Francis Group \\ LONDON AND NEW YORK
}


First published 2018

by Routledge

2 Park Square, Milton Park, Abingdon, Oxon OXI4 4RN

and by Routledge

7II Third Avenue, New York, NY 10017

Routledge is an imprint of the Taylor \& Francis Group, an informa business

(C) 2018 James Cresswell

The right of James Cresswell to be identified as author of this work has been asserted by him in accordance with sections 77 and 78 of the Copyright, Designs and Patents Act 1988.

All rights reserved. No part of this book may be reprinted or reproduced or utilised in any form or by any electronic, mechanical, or other means, now known or hereafter invented, including photocopying and recording, or in any information storage or retrieval system, without permission in writing from the publishers.

Trademark notice: Product or corporate names may be trademarks or registered trademarks, and are used only for identification and explanation without intent to infringe.

British Library Cataloguing-in-Publication Data

A catalogue record for this book is available from the British Library

Library of Congress Cataloguing-in-Publication Data

A catalog record for this book has been requested

ISBN: 978-I-I38-2। 939-7 (hbk)

ISBN: 978-I-3I5-4I52I-5 (ebk)

Typeset in Times New Roman

by Apex CoVantage, LLC 
Thanks to my mother, Linda Bliss. 


\section{Contents}

Series editor's preface

viii

Preface

xii

1 Toward a cognitive science that doesn't alienate everyone except cognitive scientists

2 Seriously, culture and language need to be taken seriously

3 Don't throw the baby out with the bathwater I:

development of religious belief

4 Don't throw the baby out with the bathwater II: evolution and experience

5 On being good researchers

6 Does reality and/or God exist ... or not? 94

Conclusion

References

115

Index 


\section{Series editor's preface}

\section{Making sense of unseen orders}

Were one asked to characterize the life of religion in the broadest and most general terms possible, one might say that it consists of the belief that there is an unseen order, and that our supreme good lies in harmoniously adjusting ourselves thereto.

(James, 1902, p. 53)

Some relevant topics have escaped their deserved research focus in our contemporary psychology. Religion is one of those. It is one of the most sophisticated inventions of the human species as it involves features that for any science are difficult to grasp. The notion of "unseen order" is conceptually a hard task for any science - not only for psychology. The unexpected outcomes in the unraveling of the overwhelming "junkness" of the genetic code or the solid strength of the graphene layer show how sciences discover unexpected features in such unseen orders. Hence, there is much to see for psychology in its looking at phenomena of religious sentiments - another domain where the origins of order is unseen but the consequences of that order govern the lives and deaths of very real human beings.

Sometimes it is hard to see the unseen at very close distance. The affect-laden nature of human existential beliefs - all of which are of central importance in religions - makes research efforts on them too close for comfort. How can I rationally analyze the basic irrationality of my existence as a person? Every effort in that direction is tampered by my own desire to modify my own ways of existing. I am - so to say - self-inclusive. Psychology in general has had to encounter that issue in many of its approaches - and psychology of religious experiences is one of those.

Psychology has been a science of paradoxes (Valsiner, 2012) - one of which is the recognition of the religious sentiments as central for its empirical efforts. Historically, our contemporary oversight of religious experience has not been the case in the history of psychology. Just the contrary - up to the 1920s, it was a major theme for thinking and curiosity by psychologists. Almost every psychologist (obviously excluding those who adhered to their deeply fixed belief in 
behaviorism) took interest in the complex phenomena of religious feelings and thinking. A century later, however, phenomena of religion are being systematically investigated only by few psychologists, and only from very few perspectives. Theoretical fashions - rather than theoretical creativity - dominate the field. This is more than a show of basic intellectual poverty of the discipline as the social world in which we all are embedded is burgeoning with complex issues anchored in a variety of religious convictions. The examples of French schoolgirls' self-decoration acts by wearing headscarves (Bowen, 2007) that became interpreted as religious self-declarations on the one hand, and the atrocities committed by the "Islamic State" against human beings and cultural heritages, on the other - are all evidence of the absolute centrality of religious sentiments in human lives and societies. And psychology as a science got its own "head start" five centuries ago when Martin Luther revolted against the neoliberal trend in the dominant Catholicism to raise funds for various earthly projects by selling insurance policies against sinfulness in the form of indulgencies. Such business practices irritated the deep believers and led to the Reformation in Europe. Aside from promoting literacy and setting the stage for further emergence of capitalism, the resulting impact on human minds was profound - the search of religiosity in one's own mind. Such a turn toward inner reflexivity about matters of the faith led to theorizing the complexities of the human soul - and to the birth of "soul science" of psychology in the eighteenth and nineteenth centuries. No surprise that issues of psychology of religious experiences occupied the interests of nineteenthcentury psychologists - with William James in the lead (James, 1902).

The present book is a refreshing new look at religion - through the lens of a cultural psychology of ecological kind - that of enactivism (Baerveldt \& Verhaggen, 2012). This perspective within others in the new area of cultural psychology is particularly potent for turning the otherwise-static area of social representations into a dynamic perspective. Building on the dynamic systems theory, the social presentations used in religious belief systems become understood as functional tools for human self-reflection. This has not been the case in cognitive studies of religion that have been focused on the centrality of categories to which the religious experiences could be reduced. Cognitive psychology's efforts to represent religions through systems of fixed categories have led to overlook of the dynamic, generative roles that inventions of religious sentiments play in societies and individual minds. At relevant moments of existential stress, new deities are created - and followed. This sets up interesting feed-forward loops that operate in non-religious practices as well (Valsiner, 1999). We set up our deities, invent rituals that - for us at least - prove that they exist - and then claim that we follow their orders. My will to believe leads to my believing in - whichever deity or any other unseeable order I might elect to be the object of my believing-in.

Religious practices are enacted - they are dramatizations created by the persons for their own purposes. Rituals are the key framework within which the connection between external acting and intra-psychological self-organization is being established. As such, they are constantly re-constructed - albeit in a relatively 
stable way. Rituals emerge in human play (Köpping, 1998) and are standardized in communal co-action as normative systems. A look at social representations that support rituals begins from the social presentations that constitute parts of the emerging new rituals. A developmental perspective on the emergence of deep and pervasive beliefs is the necessary foundation for any cultural psychology of religion. The present book makes that imperative very clear.

Cultural psychologies of today explicitly reject the axiom of genetic determinacy of higher mental actions that is at the root of the contemporary fashion for the glory of neurosciences. Without denying the neurological basis for higher psychological functions - among which religious phenomena constitute the most complex domain - the explanation of the complexity of human subjectivity by its reduction to brain mechanisms is unwarranted. Different levels of organization have their own ways of regulating their dynamics - the brain functions in ways of its own, and the psyche operates by organizational forms that are not reducible to those of the brain. Each level of complexity builds upon its nearest neighbors but also adds new features. The human psyche is generative - constantly adding new varieties of human experience to the previous ones. This happens through mediation by signs - the target field of the science of semiotics. Religious phenomena require analyses in semiotic rather than neuroscientific terms.

The major interlocutor for the author of this book is the field of cognitive science of religion. In the latter, the assumptions of the biological basis of the "cognitive architectures" prevail. In contrast to that assumption, the focus on the centrality of fluency in the sign systems of the given community is set forth. Such fluency is worked out in ontogeny - religious thinking takes place in the context of participation in the affective practices of the community. And such participation is characterized by dynamic flow of personal experiences that are constantly leading to ever-new versions of forms of belief. Some of these remain transitory, but others become fixed. Once they do become strongly held opinions, a religious belief system becomes socially dangerous. When opinions dominate, thinking ends - and the road to radicalization of the given religious belief system becomes open. Any religious system can be turned into a dogmatic basis for social stigmatization and annihilation under the circumstances of radicalization. The problem of religiously acclaimed inter-human conflicts that proliferate in our worlds today is not in the religion as such, but the fixation of its ideas and radicalization of its followers who consider the fixed ideas as legitimizing any kinds of actions.

Jaan Valsiner

Berlin, June 2017

\section{References}

Baerveldt, C., \& Verhaggen, T. (2012). Enactivism. In J. Valsiner (Ed.), The Oxford handbook of culture and psychology. New York: Oxford University Press.

Bowen, J. (2007). Why the French do not like headscarves. Princeton, NJ: Princeton University Press. 
James, W. (1902). The varieties of religious experience. New York: Longmans Green and Co. Köpping, K-P. (Ed.). (1998). The games of Gods and man: Essays in play and performance. Hamburg: LIT Verlag.

Valsiner, J. (1999). I create you to control me: A glimpse into basic processes of semiotic mediation. Human Development, 42, 26-30.

Valsiner, J. (2012). The guided science: History of psychology in the mirror of its making. New Brunswick, NJ: Transaction Publishers. 


\section{Preface}

Billig's (1996) Arguing and Thinking introduced me to a unique way of looking at psychology - which I will get to shortly - but it had a comment in the preface that has stuck with me for quite some time. He advocated taking time to wander through the shelves in a library and to read different books that one found. Billig was extolling the virtues of being surprised and discovering ideas that can be missed when one only works within the discourse of a particular field within a particular discipline. The importance of setting oneself up to be surprised is a message that lingers with me. The way that my project herein began was surprising and something that I had no intention of pursuing. Theoretical psychology and its close cousins - critical and cultural psychology - are the fields that drive my interest. One colleague expressed a desire for me to be a "meat and potatoes" psychologist, and by this he meant that I ought to be a traditional mainstream empiricist researcher. Another colleague came to my office and handed me an advertisement for a seminar at Calvin College on the cognitive science of religion and Christianity, which looked like "meat and potatoes" psychology. I sent in an application and found myself at a seminar with cognitive psychologists, and I am thankful to the seminar leader, Justin Barrett, because the whole experience set me up to be surprised.

The surprise came from the fact that I was sitting at a seminar with several mainstream psychological researchers. I hinted above how I take an approach to psychology that concerns itself with culture in a very pervasive way. I had been reading Billig because he argues that social actions are what make up psychological functioning. Psychological phenomena are topics about which people debate in life and coordinate together to establish. For example, if a young child comes to a caregiver and says that she is sad, a parent does not take the child's claim as de facto truth. Parents often must determine the legitimacy of the tears to decide if they are authentic or if they are, as we say in North America, "crocodile tears" that are put on for show. Billig points out that this social engagement is about training the child to perform sadness in a way that is taken to be authentic. The authenticity of psychological phenomena is something that is established by people and so we do not have emotions. Rather, we perform them in a way that is culturally satisfactory. 
While there are some points of divergence, this view of psychological phenomena resonates reasonably well with one that takes culture to a constitutive quality of mind. Richard Shweder (1991) is a proponent of this view and argues that culture and mind "make each other up." The field of cultural psychology points out that psychological phenomena are shaped through the flow of narratives and metaphors into which we are born. Thoughts and emotions emerge in sociointeractive actions like I described above and so the narratives and metaphors that are integral to this interaction shape possibilities for psychological/performances. This view is highly indebted to anthropological thinking and claims from scholars such a Geertz (1973) that

Undirected by culture patterns - organized systems of significant symbols man's [sic.] behaviour would be virtually ungovernable, a mere chaos of pointless acts and exploding emotions, his [sic.] experience virtually shapeless. Culture, the accumulated totality of such patterns, is not just an ornament of human experience but - the principle basis of its specificity - an essential condition for it.

This is the view on psychological phenomena that influence how I approach research.

What led to me being surprised that I was part of a seminar on the topic of the cognitive science of religion and Christianity was that I take a critical stand toward such disciplines as a cultural psychology. One of the sources of the moniker "cultural psychology" is Shweder, but there are other theorists that support this view. An important figure is Jerome Bruner and his Acts of Meaning (1990), where he argued that the cognitive revolution in psychology got it wrong. He made the case that the cognitive revolution in psychology was a reaction against behaviourism and so represented an attempt to focus on meaning in human affairs. The challenge that he raises is that the focus on cognitive processing bypasses the meaning that the cognitive revolution was supposed to recover. Meaning is something constituted in narratives and metaphors that are sociocultural phenomena, and so focussing on self-contained processing mechanisms misses meaning. It is for this reason that he advocated for a cultural psychology in contradiction to the individualistic mode that we see in cognitive science and cognitive psychology. I am heavily influenced by cultural psychology and so found myself amid several researchers that have a completely different view of the research practice of psychology.

I had not applied to study the topic of cognitive science just to spite my colleague because there was a deeper interest. The opportunity to be surprised does not come along as often as good scientists would like, and I think this happens because the pressures of academic labor require one to publish. Staying within one's own domain with colleagues that support one's own work is a good way to generate a consistent stream of publications. What challenged me was my $\mathrm{PhD}$ 
supervisor and my dissertation on Mikhail Bakhtin. I did a project on Bakhtin and how cultural psychology has neglected how the body is an important part of cultural psychology. I argued that culture is deeply embodied and shapes the realities that people experience. Bakhtin illustrates how we see the world in a way where our purview feels irreducibly real. He opens the possibility to talk about dialogue in a context where realities seem irreducible. Dialogue is not just about an interface of perspectives that can be easily relativized and altered. It is about moments when we brush up against the reality of another, and this is what makes dialogue especially tough. It is also what enables the possibility of authentic surprise: dialogue can confront what we take for granted in a deeply existential way. It was this interest in dialogue that really prompted and affirmed my engagement with the cognitive science of religion.

This book is an attempt to enable surprise by escaping the trap of disciplinary thinking. The strong cultural position that I take herein is designed to provoke researchers in the cognitive science of religion. It is an attempt to start from William James to show how the cognitive science of religion bypasses meaning and the specific content of religion. This bypass amounts to a discipline that is good for cognitive scientists but remains largely ineffective in terms of its application in everyday life. I attempt to challenge the common disciplinary thinking that is often seen in the cognitive science of religion. The seminar at Calvin and community of researchers have been very gracious with my critiques and provided me with a body of work that orients me to the discipline.

In the spirit of dialogue, however, I also attempt to push work in cultural psychology in a direction that takes cognitive science seriously. Critical and cultural views of psychology initially started out in a place where they were engaged with mainstream approaches. They have since formed their own communities and have generated their own genres of publication. As an active scholar in the field who has reviewed countless articles and edited some volumes, I have noted a potential for intellectual hubris. I offer a way to think about cognitive science that gives proper due to recent developments in the field.

This book is an effort to be provocative on the one hand. It provokes the cognitive science of religion to think through its presuppositions and challenges weaknesses in the theory. It provokes critically and culturally oriented theorists to take seriously the work that is going on in the cognitive science of religion. Such provocations are what constitute the possibility to build transdisciplinary bridges, on the other hand. Creating a situation of provocation makes enemies on both sides, but it also is what we need to do to engage in dialogue. Confrontation sets up the conditions to see different purviews, and this sort of conversation starter is what this book is intended to be about. 


\title{
Toward a cognitive science that doesn't alienate everyone except cognitive scientists'
}

\begin{abstract}
This introductory chapter discusses the phenomena that preoccupies this book: religious belief taken for granted as self-evident truisms. A challenge to studying these phenomena is that researchers are "speaking a different language" than the participants in the studies. There seems to be an impasse, and this chapter is about looking to William James as inspiration for how to overcome it. James was against an abstract notion of belief where something can be separated from a belief about the thing. Belief is misunderstood when we separate it from a thing that we have a belief about because belief necessarily involves knowledge about something. He was also against a disembodied notion of belief. Experience includes how our senses entwine with happenings in life. The flow of human experience includes continual relation among ideas and the body, which means that it does not make sense to abstract belief from the concrete materiality of the world. This chapter outlines how an impasse between researchers and participants emerges because the former take an abstract and disembodied approach to belief. The quarrel with research is not with the dismissal of religious belief as an accident, but the underlying presuppositions of what religious belief is. This chapter thereby outlines how the impasse emerged and presents what we can do to move forward.
\end{abstract}

\section{Introduction}

Blake Wenner was a student for whom I supervised a research project on the topic of religious doubt. He was interested in examining how Christian believers developed and reconciled doubts. His desire to do this research came from his own experience where he saw belief held together by dubious rationalizations and thinly veiled self-interest. He recruited and interviewed participants who were Christian believers and what they said, for him, was disappointing. 
Instead of participants explaining their rationale for reconciling doubts to fortify beliefs, they often had no clear rationale as to how religious belief was sustained. The participants talked about the dealing with religious doubt as a simple act of belief that just fit with life. For example:

\begin{tabular}{|c|c|c|}
\hline Turn & Speaker & \\
\hline I & Blake & $\begin{array}{l}\text { yeah, so um.... in light of your questioning of your } \\
\text { beliefs and things such as where has Jesus' body gone } \\
\text { and, um the ascension of things that aren't quite clear, } \\
\text { how are how are these uhm beliefs clarified like how } \\
\text { have you resolved... }\end{array}$ \\
\hline 2 & Participant I & I don't worry about em \\
\hline 3 & Blake & you don't worry about em \\
\hline 4 & Participant I & no. \\
\hline 5 & Blake & so um, you would you would say you wouldn't. . . \\
\hline 6 & Participant I & I trust. \\
\hline 7 & Blake & $\begin{array}{l}\text { you trust. So rationale, you wouldn't put rationale at } \\
\text { the forefront of picking apart those issues }\end{array}$ \\
\hline 8 & Participant I & $\begin{array}{l}\text { oh, I guess I trust that God if he created the world } \\
\text { (laughs) then he knows what he's doing }\end{array}$ \\
\hline
\end{tabular}

Participants described belief, but they did not spend a lot of time wondering why they believed. They illustrated how belief, like in this quote above, is a simple thing that becomes a matter of trust and not one worthy of preoccupation. It was just taken for granted as a truism, and participants did not know why they believed per se because they simply trusted. Blake did not get what he was looking for, and the question is, "Why?"

Blake is typical of researchers in a way that helps us understand why he did not get what he was looking for. It was like he was speaking a different language than his participants. He was talking about beliefs grounded in careful rationale, and they just didn't talk in these terms. They were talking about a life that simply included belief. While Blake's engagement was kindly agnostic, there are similar instances of researchers or academics whose tone is not so nice. Some academics shout at religious people that they are irrational and ignore evidence (e.g., Dawkins, 2006; Dennet, 2006). Religious people shout back that a researcher just does not "get it." Researchers and believers can come from such different perspectives that they are living in different realities. It is as if the two parties are in different worlds, and my point is that this divergence is the central problem.

This book is about this impasse and how to overcome it by expanding the way we approach the psychology of religion. While there are many kinds of psychological research, I am going to focus in on just one: the cognitive science of 
religion (CSR; Barrett, 2007). CSR is a field within psychology, but its impact is far ranging as it informs a substantial amount of public and academic discussion (e.g., Ball, 2012; Krakovsky, 2012). CSR is a good approach to engage because it represents the discipline of psychology well as cognition has been identified as central to the discipline of psychology (e.g., Thagard, 2005). As such, I seek to explicate an approach that accommodates both religious believers and psychologists by way of a provocative discussion of CSR. To identify and move beyond this impasse, I am going to look to the past by discussing one of the founders of modern psychology: William James. He had a vision for psychological research that is quite different from CSR, and looking back to him reveals a way of approaching the psychology of religion that can surmount the impasse (see Cresswell et al., 2017). This introductory chapter outlines James' ideas and serves as the context for the remainder of the book. It will first address belief as James described it and then show how it is bypassed in CSR. From there, I will return to James and discuss truth as a springboard for the rest of the book.

\section{William James and the bypass of belief}

René Descartes has arguably been one of the most influential thinkers who has shaped our understanding of what things like belief mean. He influenced Immanuel Kant such that they both shared very similar ideas about things like belief (for a sustained discussion see Taylor, 1989). Both Kant and Descartes have left us with a heritage that treats belief as abstract and disembodied (see Harré, 2002). To refer to belief as abstract is to say that it is not necessarily tied to what is happening in life because it is an ethereal mental property. It involves conceiving of belief as not necessarily tied to the actual happenings of life because it belongs to the realm of subjective mind. To say that belief is disembodied refers to Descartes' famous split between the mind and body. He treated the mind as abstract in its ethereal nature, and this abstractness meant that is was not necessarily tied to the body or anything physical. The body is not tied to belief because it is abstracted from it. William James took a contrary approach.

\section{Belief in relation to something: against abstract belief}

James was critical of the notion of an abstract belief (James, 1996/1912). An abstract and disembodied approach to belief involves a separation of something from a belief about the thing. He was against the idea that we can sensibly talk about belief being separate from something in the way that an abstract and disembodied approach implies. Belief is misunderstood when we separate it from a thing that we have a belief about because belief necessarily involves knowledge about something. That is, belief involves knowing about something because we cannot have a belief about nothing. The about is crucial if we want to understand how belief works in life. Consider the following conversational excerpt as an illustration. 


\begin{tabular}{lll}
\hline Interview I, page I5 & \\
\hline Turn & Speaker & \\
\hline I & Participant I & $\begin{array}{l}\text { and I I've can't think that you know when you } \\
\text { pray, help me to forgive this person }\end{array}$ \\
2 & Blake & $\begin{array}{l}\text { Yeah } \\
\text { and love this person, that's so very important } \\
\text { yeah } \\
\text { and I have I don't feel that I have a problem with } \\
\text { forgiving because I know that there is a god out } \\
\text { there that will help me }\end{array}$ \\
\hline & $\begin{array}{l}\text { Participant I } \\
\text { Participant I }\end{array}$ &
\end{tabular}

This is a discussion where a participant talked about a belief that one should pray for someone when that person bothers one. The first use of knowledge shows up in "you know," and this is a common conversation filler (turn 1; ten Have, 2002). Grammatically, it imputes knowledge to Blake and implies something about which there is shared knowledge. When participant 1 says "you know," it is about something, and this thing is the act of praying for someone. The action and potential someone to "pray for" are absolutely necessary for the belief to make sense. Without connection to this wider context, Blake would have no sense of what the participant means. This word "know" is refined in turn 5 to show us how believing in praying to forgive someone involves knowledge about God. Turn 5 shows us how belief works in life as connected to a thing "out there" beyond one's own thoughts: God. As we can see in the example above, belief shows up in life in a way that involves knowledge about something "out there" beyond one's own subjective thoughts. James' argument extends to religious belief and shows us how, without something tied to it, religious belief is not sensible. The sophistication of his point lies in how he is not offering apologetics but a way to approach religious belief.

James (1981/1907, 1956/1897, 1996/1912) considered how belief functions in life to show how our religious beliefs are about something. He highlighted how belief is about relationships in the sense that one can have knowledge about another thought or another thing, but it always involves a relation to another thing. All things that fall under the banner of belief involve relationships so that we do not have any element of belief that is isolated and on its own. That is, every belief is related to something else, and it simply does not make sense to talk about a belief that stands as a subjective isomorphic proposition. Belief is a kind of knowledge in relation to something else, and so we always have religious belief in relation to another thing.

This approach to belief is what enables James to break us out of the abstract approach we get from Kant and Descartes, which is important because abstract conceptions of belief simply miss the phenomenon. This position has a huge implication for how we think of ideas like subjective mind and objective reality. James wrote: 
Just so, I maintain, does a given undivided portion of experience, taken in one context of associates, play the part of the knower, of a state of mind, of 'consciousness'; while in a different context the same undivided bit of experience plays the part of the thing known, of an 'objective' content . . . since it can figure in both groups simultaneously we have every right to speak of it as subjective and objective both at once.

(James, 1996/1912, p. 10)

To many people, speaking in terms of belief being both objective and subjective seems strange, but it provides a very helpful idea. A belief in another belief can be subjective, but the web of relations involved in belief never stops there in selfcontained subjectivity. All belief eventually comes into relation with something in the world we share with others. Eventually, we come to a relation to something that is not just inside our heads and is necessarily never abstract. Take a close look at the following illustrative conversation.

Interview 2, page 21

\begin{tabular}{|c|c|c|}
\hline Turn & Speaker & \\
\hline I & Blake & $\begin{array}{l}\text {... do you find that questions are resolved by way of } \\
\text { moments of rational clarity }\end{array}$ \\
\hline 2 & Participant 2 & $\begin{array}{l}\text { are resolved by way of moments of rational clarity did } \\
\text { you say }\end{array}$ \\
\hline 3 & Blake & yeah \\
\hline 4 & Participant 2 & $\begin{array}{l}\text { gosh I wish something was totally clear all the time, } \\
\text { it'd be nice you know rational clarity to me is easier } \\
\text { to see than spiritual clarity and so again sometime } \\
\text { although deep down in the bottom of my heart I'm } \\
\text { doing something just because it feels right. But again } \\
\text { if it does feel right and I have these two equal things } \\
\text { I'll go down with what I think is right or what I feel is } \\
\text { right I just try to do the right thing }\end{array}$ \\
\hline 5 & Blake & but but \\
\hline 6 & Participant 2 & $\begin{array}{l}\text { and so, and the question about if you give a man a fish } \\
\text { he will eat for the day then starve, if you teach him } \\
\text { how to fish then he'll live all day but if a guy's hungry } \\
\text { I'm gonna give him some fish you know later on I'll } \\
\text { teach him how to fish but you know but if he's hungry } \\
\text { to me the right thing is to give him some food at that } \\
\text { moment. Is it enabling I don't know but it just feels } \\
\text { right to me to help somebody }\end{array}$ \\
\hline
\end{tabular}

If we look at the structure of this conversation, we see how the participant articulates his belief. Turn 4 involves discussing how something just "feels right," and so it would seem to contradict James by not leading to something outside the participant's head. It reads like a description of a deep solipsistic experience. In turn 6 , 
however, the participant transitions to talking about doing the right thing. In the way the participant talks, we see how religious belief ties to an actual activity like helping someone. The structure of the answer reveals a belief in relation to an objective action in the world. It is insufficient to say that the belief is just subjective because it always points beyond an individual to something outside. To paraphrase James (1981/1907), if one dies and stops believing in something, the object does not disappear, and it continues on without any single individual: “. . . I could perfectly well define [belief], what the knowing actually and practically amounts to - leading towards, namely, and terminating in percepts, through a series of transitional experiences which the world supplies" (James, 1996/1912, p. 25). Take the example of Participant 1 knowing that there is a God "out there." Obviously, it may seem like God is a subjective thing because we cannot find a conclusive empirical case for its existence. If Participant 1 dies, however, the notion of God is not going to die with him, and so it is not properly subjective. James, contra Descartes, realized that belief does not fit with the subjective-objective dualism that people tend to take for granted.

\section{Belief in relation to something: against disembodied belief}

Religious belief, then, is not simply dismissible as a subjective thing, and it is not simply an objective thing. If belief were purely separate from the world and not in relation to something, then we could say that it is abstract. We cannot say so about belief, and so it is not abstract. What about the notion of being disembodied?

Experience involves the body, and so addressing this question involves a discussion of experience (Baerveldt \& Voestermans, 2005; Cresswell, 2012; Thompson, 2007). What James (1981/1907, 1996/1912) meant by experience can be understood if we start from basic experience and then work to the more complex notion of religious belief. James goes as far as to claim that belief is best characterized in terms of pure experience, which is the name for a collection of "sensible natures" (1996/1912, p. 27). Experience, at its most basic level, includes how our senses entwine with happenings in life. When one looks out at the environment in which one is reading, for example, light rays stimulate cells on the retina, and the activity of cells happens in relation to what is in life. This is a simplistic example of experience and highlights how experience involves a flow of sensory stimulation occurring in relation to the world. We move through life with our bodies responding in relation to things, and so one experience passes into another in a constant flow.

The constant flow of experience involves more complexity than merely being stimulated by an environment. If one were to sit and read in a café, one could look around and see the stimuli in terms of coherent and meaningful unities like "tables" and "chairs." Previous flows of experience such as learning the names for such things in childhood bleeds into the current flow to give sensory stimulation shape. Included in the previous experiences that are brought into the present are emotions and personal histories. A café may feel a certain way because of previous experiences like, for example, spending time with a caregiver at cafés that gives the tables and chairs emotional valence. James (1996/1912) pointed out that experience includes a constant flow of stimuli in relation to one another and 
in relation to psychological phenomena like concepts and emotions. He pointed out how experience involves an inseparable relation between psychological phenomena and physiological ones. The flow of human experience includes continual relations among a range of elements, and so it does not make sense to abstract conscious phenomena like belief from the concrete materiality of the world. Hence, he argued against the idea that that the "thought-of [an] object is hid away inside the thinking subject" (1996/1909, p. 19) because the past can impact us directly to shape what is experienced as real. Belief is something that is experienced in the flow of the life that we live and experience as real. It is part of the reality that humans experience.

Religious belief is thereby entwined with physical life. Beliefs relate to all other experiences insofar as they are in relation to concrete particulars like light and touch. They involve a complete way of relating to the world that shapes reality that feels objective. James thereby described belief as part of an interconnected web of past and present experiences shaping a reality that includes belief. When someone is faced with a situation, beliefs come to bear in their experiential sense and shape immediate bodily dispositions. Instead of deciding about what to do in life on intellectual (i.e., abstract and disembodied) grounds, we "find ourselves believing, we hardly know how or why" (James, 1956/1897, p. 9).

The question I raise is an important one: Do psychologists, and those involved in CSR in particular, address belief as it shows up in life, in its non-abstract and embodied quality? I don't think so. Blake, for example, was looking for abstract and disembodied rationale for belief that does not include belief as a whole way of experiencing the world. It is an important question to decide if Blake is typical because, if psychologists are giving back to the community like good citizens do, then we ought to have something to say about the actual phenomena of belief as it shows up in life. The next few pages propose why the answer to the question above is partly no.

\section{Psychology of religion: cognitive science of religion and bypassing belief}

Dennet's (2006) Breaking the Spell: Religion as Natural Phenomenon describes religion as being the accidental result of a "hyperactive agency detection device." "Device" refers to an automatic mechanism that operates in the mind. Humans are supposedly endowed with a mechanism for detecting agency in the world around us. It is "hyperactive" insofar as it kicks into gear and processes all sorts of events as if they were caused by agents. The result is a supposed mechanism that tends to overproduce the perception of agency lying behind natural happenings in the world. The wind rattles a shrub as we walk past and jump back as if there is a nefarious thing intentionally prompting such happenings (see Dennet, 1996).

Other researchers were picked up by the popular media with the claim that “Analytic Thinking Promotes Disbelief” (Gervais \& Norenzayan, 2012). Titles like this betray a claim that religion is a product of mechanisms like the hyperactive agency detection device, but controlled rational thinking overriding such intuitive mechanisms leads away from religious belief. People can supposedly 
override these primal leftovers of the mind when they think more carefully and analytically. The implications of such ideas can be seen in the work of wellknown critics of religion like Richard Dawkins: "[t]he general theory of religion as an accidental by-product - a misfiring of something useful - is the one I wish to advocate" (2006, p. 188).

The quarrel with this view is not to quarrel with the dismissal of religious belief as an accident, but the underlying presuppositions of what religious belief is. There is good reason to suspect that this approach, while offering valuable insights in its own right, bypasses religious belief as it plays a role in life. This reason has to do with the way that psychologists have generally approached religion. Usually, they advocate an agnostic approach to religion that considers the topic from a "rigorously" scientific perspective (Argyle, 2000).

At a general level, such a perspective is hard to maintain because studying religion is not an easy task. Hall et al. (2008) pointed out how this challenge is attested to the availability of over 100 instruments attempting to measure religion or aspects thereof. They noted that the challenge is compounded with how the definition as to what even counts as religious shifts with the researchers. In some cases, studies are about religious behaviors such as going to attend a service. Others involve an attempt to measure behaviors and/or more ethereal-experiential aspects of religious experience (see also Kapuscinski \& Masters, 2010). These efforts reflect an attempt to get at a sense of connectedness associated with spirituality as opposed to institutional religious behavior or ascent to dogma (see Meezenbroek et al., 2012). What Hall et al. (2008) note is that authors often overstate their conclusions about religion in general when there is so much disagreement as to what the phenomenon is and how it is being measured. Researchers seem to continually cling to the notion that some sort of religion in general must underlie all of this diversity:

Although the empirical stream of religious measurement has developed and supported a multi-dimensional model of religiousness that resists global assessments, much of the research on religion ... assumes that "religiousnessin-general" actually exists. As such, it attempts to measure the intensity of religiousness (belief, experience, strength, value, etc.) in order to locate people on a continuum between "very religious" and "not religious". . .

(Hall et al., 2008, p. 154)

Despite imprecise concepts and a need for contextual social/theological informed research, a context-free approach to religion continues to be popular. It is in this vein that authors such as Underwood (2011) argue that religion and spirituality are multidimensional constructs with many features reflective of a single underlying factor. Developments such as the Daily Spiritual Experience Scale are designed to assess such variability while being opaque enough to even work with people who would not call themselves religions. Measuring experience instead of beliefs is taken to get at this underlying construct (see also Underwood \& Teresi, 2002). 
The literature points to a recognition that it is difficult to access underlying unified constructs, yet such covering laws must nevertheless be present. Chirkov (2016) notes that this paradigm is one where researchers search for natural laws underlying behavior. That is, researchers are interested in uncovering the truth about reality in a way that has been referred to as naturalism (see Reber, 2006; Brown \& Stenner, 2009). Naturalism involves trying to understand the truth of reality by uncovering the laws by which the natural world works. This approach is that one has found truth when one finds the mechanical laws by which the world works.

In the early 1960s, psychologists began to speculate on how the mind worked in order to uncover the naturalist laws of mental operations. Alan Turing - one of the widely accepted forerunners of the cognitive revolution that shapes contemporary psychology (see Dawson, 2001) - developed the idea that humans operated on computational principles, where computation was defined as algorithms or rules (Boden, 2006, p. 173). This person-as-computer perspective put forward by Turing was that the computer observed symbols, processed such symbols according to a set of rules, and then responded on the basis of the outcome of those rules. One author writes that "[c] ognitive skills are realized by production rules" where "[p]roduction rules are if-then or condition-action plans. The if, or condition, part specifies the circumstance under which the rule will apply. The then, or action, part of the rule specifies what to do in that circumstance" (Anderson, 1998, pp. 59, 63).

It is on this heritage that much of contemporary psychology is built (see Thagard, 2005). When authors argue for an agnostic scientific approach, they mean a science that uncovers natural laws about mental computation and outputs. It involves seeking to explicate psychology in terms of natural mechanical laws of human functioning. The result is an approach to religious belief shaped to fit a naturalistic bias. The rigorous scientific approach is a form of naturalism that shows up in in the psychology of religion as a concern with computational processing laws. ${ }^{3}$ Discovering naturalist predictors and processing outcomes associated with religiosity reflects a concern with what psychology is taken to be about. This kind of approach is what is embodied in a "rigorously" scientific perspective. Nowhere is this heritage clearer than in CSR. The sort of production-rule-based naturalism manifests in the CSR, and writing about practices in this field can be generalized back to the psychology of religion in general. CSR, for example, underlies the work on the Hyper-Active Agency Detection Device that I discussed above (e.g., Guthrie, 1993; Whitehouse, 2004).

This kind of naturalism bypasses the phenomena of belief as it was outlined above in our discussion of James. An approach that is scientific via a naturalist fixation can come at the expense of everyday life (James, 1981/1907). Consider as an example how some authors of the naturalist ilk have explicitly stated that they are not interested in what belief is about because this is simply not a relevant focus (e.g., Pyysiäinen, 2002; Guthrie, 2002). That is, belief as a non-abstract and embodied phenomenon is not a concern. Religious belief, as it shows up in life, is part of the reality humans experience and is not lived as a cognitive mechanism. Consider an illustration from Blake's interviews. 
Interview 5, page 20

\begin{tabular}{|c|c|c|}
\hline Turn & Speaker & \\
\hline I & Blake & $\begin{array}{l}\text { yeah, uhm. so why would you say just expanding } \\
\text { on that, that you rely more on your feelings or } \\
\text { intuition }\end{array}$ \\
\hline 2 & Participant 5 & $\begin{array}{l}\text { uhm, ... well, it's not, for me it's not fleeting, it's } \\
\text { not uhm, wispy or insubstantially. That stuff comes } \\
\text { off really powerfully }\end{array}$ \\
\hline 3 & Blake & Mhmm \\
\hline 4 & Participant 5 & $\begin{array}{l}\text { with me and part of that's being so harmed when } \\
\text { I was a child, those intuitive things go way up }\end{array}$ \\
\hline 5 & Blake & Mhmm \\
\hline 6 & Participant 5 & $\begin{array}{l}\text { it's like God somehow uses your brain, to pay } \\
\text { attention in ways when you've been harmed, that } \\
\text { doesn't happen with other people and probably } \\
\text { has to do with you know brain development }\end{array}$ \\
\hline 7 & Blake & yeah \\
\hline 8 & Participant 5 & $\begin{array}{l}\text { it's the stuff that's I think of it now. So it's not } \\
\text { wispy it's not insubstantial it's really powerful }\end{array}$ \\
\hline
\end{tabular}

This quote would seem to support the idea that a cognitive mechanism is at stake with the mention of brain development. This participant, however, is talking about the experiential power of belief. God is described as part of reality by the implicit presupposition that God uses one's brain. A proponent of CSR would say that this experience is irrelevant because it only matters what happens underneath in the realm of naturalist mechanisms. This position is fine for cognitive scientists who believe - in the full sense of the term - in naturalist laws.

Belief, on a naturalist CSR approach, is abstract in the sense that the specifics that belief is about are simply not addressed. The hyper-active agency detection device, for example, allows for any kind of super-agent to fall into the scope of the mechanism's operation but a belief is rarely about a non-specific super-agent. For example:

Interview 2, page 8

\begin{tabular}{|c|c|c|}
\hline Turn & Speaker & \\
\hline I & Participant 2 & $\begin{array}{l}\text { so now and at this one point yes I believe in a virgin } \\
\text { no I don't no I didn't yes I do no I don't. I think } \\
\text { that my faith is now at the point that if there was } \\
\text { something that came along that proved scientifically } \\
\text { that Jesus was conceived by Joseph that it wouldn't } \\
\text { affect my faith at all because again all things are } \\
\text { possible through Jesus ... it just isn't that matter } \\
\text { now that would be a serious problem for a lot of } \\
\text { Christians to believe that Jesus wasn't from a virgin } \\
\text { relationship but that wouldn't be a problem form me }\end{array}$ \\
\hline
\end{tabular}


Interview 2, page 8

\begin{tabular}{lll}
\hline Turn & Speaker & \\
\hline 2 & Blake & $\begin{array}{l}\text { Right } \\
\text { disproving the resurrection would be cause I think } \\
\text { that's pretty essential }\end{array}$ \\
\hline Interview 3, page 3 & \\
\hline Participant 3 & $\begin{array}{l}\text { there's an enormous amount of opportunity to think } \\
\text { about the experience of Christ and his life with an } \\
\text { accent on ah, his suffering and his role as the redeemer }\end{array}$ \\
\hline
\end{tabular}

In both of these examples, the beliefs are about specific features of the faith. What practically matters in life is what beliefs are specifically about. A general mechanistic rule is too abstract to grasp what this belief entails. The approach taken by CSR is also disembodied insofar as experience is bypassed. Moreover, a specific religious belief involves particular content that is integrated with emotional entanglement with the world. The abstract mechanisms bypass this integration and lose what it means to have the experience of religious belief.

For those outside of the CSR belief system, naturalistic laws of functioning are unhelpful because the psychological reality that matters in life is bypassed. When truth is defined as only finding natural mechanisms and processing rules, we actually bypass what religious belief is. The result is that belief, as it tends to be studied, substantially diverges from the way it shows up in life. It is here that we can see the impasse that Blake and other researchers reach. The dismissal of belief as a processing mechanism is met with a response that what is dismissed is what really matters.

\section{Moving forward}

James shows us how religious belief works in a way that is concrete and embodied. A related issue is that how we think of the scientific belief can be abstract and disembodied. Naturalism in CSR exemplifies this issue because a claim in CSR is taken to be true when it represents what natural mechanisms are at play. For example, if a researcher claims that the hyper-active agency detection device produces the ability to perceive a super-agent, a researcher is making the claim about a mechanism that plays a role in the production of religion (e.g., Boyer, 2001). It is taken to be a true claim because it represents a natural process that is really happening. CSR, for example, is abstract in the way that naturalism bypasses what belief is about. A super-agent and experience that a religious belief entails is treated as irrelevant when scientific truth is approached in this manner. It is disembodied in the sense the experience of life is little more than a source of stimulation. This bypass of belief comes from an approach to science where truth is abstract and disembodied. The truth claims in CSR are about general naturalistic mechanisms that don't bear much relevance to religious beliefs as they show up in life. 


\section{References}

Anderson, J. (1998). Production systems and the ACT-R theory. In P. Thagard (Ed.), Mind readings: Introductory selections on cognitive science (pp. 59-76). Cambridge, MA: MIT Press. Argyle, M. (2000). Psychology and religion: An introduction. New York: Routledge.

Atran, S. , \& Norenzayan, A. (2004). Religion's evolutionary landscape: Counterintuition, commitment, compassion, communion. Behavioral and Brain Sciences, 27, 713-770.

Baerveldt, C. , \& Verheggen, T. (2012). Enactivism. In J. Valsiner (Ed.), The Oxford handbook of culture and psychology (pp. 165-190). New York: Oxford.

Baerveldt, C. , \& Voestermans, P. (2005). Cultural psychology and the normative structure of reality. Theory and Psychology, 15, 449-473.

Bakhtin, M. (1981). The dialogic imagination: Four essays by M. M. Bakhtin ( C. Emerson \& M. Holquist , Trans.). Austin, TX: University of Texas Press. (Original Russian Publication 1975) Bakhtin, M. (1986). Speech genres and other late essays ( V. McGhee, Trans.). Austin, TX: University of Texas Press. (Original Russian Publication 1970-1979)

Bakhtin, M. (1990). Author and hero in aesthetic activity ( V. Liapunov \& K. Brostrom , Trans.). In M. Holquist \& V. Liapunov (Eds.), Art and answerability: Early philosophical essays. Austin, TX: University of Texas Press. (Original Russian Publication 1979)

Bakhtin, M. (1993). Toward a Philosophy of the Act ( V. Liapunov , Trans.). Austin, TX: University of Texas Press. (Original Russian Publication 1986)

Ball, P. (2012). Is rationality the enemy of religion? Nature. doi:10.1038/nature.2012.10539.

Retrieved from www.nature.com.

Barrett, H. , \& Kurzban, R. (2006). Modularity in cognition: Framing the debate. Psychological Review, 113(3), 628-647.

Barrett, J. (2004). Why would anyone believe in god? Plymouth: AltaMira.

Barrett, J. (2007). Cognitive science of religion: What is it and why is it? Religion Compass, 1(6), 768-786.

Barrett, J. (2008). Coding and quantifying counterintuitiveness in religious concepts: Theoretical and methodological reflections. Method and Theory in the Study of Religion, 20, 308-328.

Barrett, J. (2012). Born believers: The science of children's religious belief. Toronto: Free Press. Barrett, J. , Burdett, E. R. , \& Porter, T. (2009). Counterintuitiveness in folk tales: Finding the cognitive optimum. Journal of Cognition and Culture, 9, 271-287.

Barrett, J. , \& Richert, R. (2003). Anthropomorphism or preparedness? Exploring children's god concepts. Review of Religious Research, 44(3), 300-312.

Barrett, J. , Richert, R. , \& Driesenga, A. (2001). God's beliefs versus mother's: The development of non-human agent concepts. Child Development, 72(1), 50-65.

Belzin, J. (1997). The historicultural approach in the psychology of religion: Perspectives for interdisciplinary research. Journal for the Scientific Study of Religion, 36(3), 358-371.

Belzin, J. (1999). Religion as embodiment: Cultural-psychological concepts and methods in the study of conversion among "Bevindelijken." Journal for the Scientific Study of Religion, 38(2), 36-253.

Belzin, J. (2005). A way out of crisis? From völkerpsychologie to cultural psychology of religion. Theory \& Psychology, 15, 812-838.

Belzin, J. (2010a). Religion and self: Notion from a cultural psychological perspective. Pastoral Psychology, 59, 399-409.

Belzin, J. (2010b). Towards cultural psychology of religion: Principles, approaches, applications. New York: Springer.

Benson, C. (1991). The cultural psychology of self. London: Routledge.

Bering, J. (2006). The folk psychology of souls. Behavioral and Brain Sciences, 29, 453-498.

Bering, J. (2010). God instinct: The psychology of souls, destiny, and the meaning of life. London: Nicholas Brealey.

Bering, J. (2011). The belief instinct: The psychology of souls, destiny, and the meaning of life. New York: W. W. Norton \& Co.

Bering, J. , Blasi, C. , \& Bjorklund, D. (2005). The development of 'afterlife' beliefs in religiously and secularly schooled children. British Journal of Developmental Psychology, 23, 587-607.

Bhabha, H. (1994). The location of culture. New York: Routledge.

Billig, M. (1996). Arguing and thinking: A rhetorical approach to social psychology (2nd ed.).

New York, NY: Cambridge University Press. 
Bishop, R. (2007). The philosophy of the social sciences. New York: Bloomsbury Academic. Boden, M. (2006). Mind as machine: A history of cognitive science. New York: Oxford University.

Boyer, P. (2001). Religion explained. New York: Basic books.

Boyer, P. , \& Ramble, C. (2001). Cognitive templates for religious concepts: Cross-cultural evidence for recall of counter-intuitive representations. Cognitive Science, 25, 535-564.

Brown, S. (2012, June 26). Analytical thinking promotes disbelief in experimental psychology. Huffington Post. Retrieved from www.huffingtonpost.com

Brown, S. , \& Stenner, P. (2009). Psychology without foundations: History, philosophy and psychosocial theory. Thousand Oaks, CA: Sage.

Bruner, J. (1990). Acts of meaning. Cambridge, MA: Harvard University Press.

Buller, D. (2005). Adapting minds: Evolutionary psychology and the persistent quest for human nature. Cambridge, MA: MIT Press.

Burkitt, I. (2013). Self and others in the field of perception: The role of micro-dialogue, feeling, and emotion in perception. Journal of Theoretical and Philosophical Psychology, 33(4), 267-279.

Cerbone, D. (2006). Understanding phenomenology. Chesham: Acumen.

Chirkov, V. (2016). Fundamental of research on culture and psychology. New York: Routledge. Chirkov, V. I. (2009). Critical psychology of acculturation: What do we study and how do we study it, when we investigate acculturation? International Journal of Intercultural Relations, 33(2), 94-105.

Cohen, E. , Lanman, J. , \& Whitehouse, H. (2008). Common criticisms of the cognitive science of religion - answered. The Council of Societies for the Study of Religion Bulletin, 37(4), 112-115.

Cole, M. (2003). Cultural psychology: A once and future discipline. Cambridge, MA: Harvard University Press.

Cole, M. (2006). Culture and cognitive development in phylogenetic, historical, and ontogentic perspective. In W. Damon \& R. Lerner (Eds.), Handbook of child psychology Volume II (pp. 636-683). Hoboken, NJ: Wiley.

Corcoran, T. (2009). Second nature. British Journal of Psychology, 48(2), 375-388.

Cosmides, L. , \& Tooby, J. (1992). Cognitive adaptations for social exchange. In J. Barkow , L. Cosmides, \& J. Tooby (Eds.), The adapted mind: Evolutionary psychology and the generation of culture (pp. 163-228). New York: Oxford University.

Cosmides, L. , \& Tooby, J. (1994). Origins of domain specificity: The evolution of functional organization. In L. Hirschfels \& S. Gellman (Eds.), Mapping the mind: Domain specificity in cognition and culture (pp. 85-116). Cambridge: Cambridge University.

Cosmides, L. , \& Tooby, J. (1997). Evolutionary psychology: A primer. Center for Evolutionary Psychology, University of California Santa Barbara. Retrieved from

www.cep.ucsb.edu/primer.html

Cresswell, J. (2011). Being faithful to ourselves: Bakhtin and a potential postmodern psychology of self. Culture \& Psychology, 17, 462-479.

Cresswell, J. (2012). Including social discourses and experience in research on refugees, race, \& ethnicity. Discourse \& Society, 23(5), 553-575.

Cresswell, J. (2014). Can psychology \& religion get along: Towards a pragmatic cultural psychology of religion that includes meaning and experience. Theoretical and Philosophical Psychology, 34(2), 133-145. doi:10.1037/a0033042

Cresswell, J. , \& Baerveldt, C. (2011). Bakhtin's realism, embodiment, and the dialogical self: Towards a re-visioning of the dialogical self. Culture \& Psychology, 17, 263-277.

Cresswell, J. , \& Baerveldt, C. (2016). On being good researchers: Virtue, sympathetic coexperience and polyphonic unmasking. In T. Corcoran \& J. Cromby (Eds.), Joint action: Essays in honour of John Shotter (pp. 102-119). Flourance: Routledge.

Cresswell, J. , \& Smith, L. (2012). Embodying discourse analysis: Lessons learned about epistemic \& ontological psychologies. Discourse \& Society, 23(5), 619-625.

Cresswell, J. , \& Teucher, U. (2011). Embodiment and language: M. M. Bakhtin on ontogenetic development. New Ideas in Psychology, 29, 106-118.

Cresswell, J. , Wagoner, B. , \& Haye, A. (2017). William James reconsidered: Introduction to a special issue commemorating the 125th Anniversary of 'Principles of Psychology'. New Ideas in Psychology, 46, 1-6. 
Cresswell, J. , Wenner, B. , \& Howell, M. (2014, November). New vistas from old theories: Working through the complexities of religious belief through radical empiricism. Paper Presented at the Society for the Scientific Study of Religion Conference, Indianapolis. Cromby, J. (2015). Feeling bodies. New York: Palgrave Macmillan.

Danziger, K. (1990). Constructing the subject. New York: Cambridge University Press. Dawkins, R. (2006). The God delusion. Boston, MA: Houghton Mifflin.

Dawson, M. (2001). Understanding cognitive science. Malden, MA: Blackwell.

Dennet, D. (1996). The intentional stance. Cambridge, MA: MIT Press.

Dennet, D. (2006). Breaking the spell: Religion as natural phenomenon. New York: Viking.

Derksen, M. (2007). Cultivating human nature. New Ideas in Psychology, 25, 189-206.

Derksen, M. (2010). Realism, relativism, and evolutionary psychology. Theory \& Psychology, 20, 189-206.

Donald, M. (2001). A mind so rare: The evolution of human consciousness. New York: Norton. Edman, L. (2014). The faithful brain: Using the science of faith in our faith practice. Psychology and Spiritual Formation: The 3rd Annual Conference of the Center for Christian Thought, La Mirada, CA.

Edman, L. (2015). Applying the science of faith: The cognitive science of religion and Christian practice. Journal of Psychology and Christianity, 34, 238-249.

Edman, L. , Vermeer, J. , Chambers, H. , \& Wiggers, T. (2015). Mentalizing and prayer: The relationship of theory of mind and knowing a personal god. The Society for the Scientific Study of Religion 2015 Annual Conference, Newport Beach, CA.

Edwards, D. (1997). Discourse and cognition. Thousand Oaks, CA: Sage.

Elman, J. , Bates, E. , Johnson, M. , Karmiloff-Smith, A. , Parisi, D. , \& Plunkett, K. (1998).

Rethinking innateness: A connectionist perspective on development. Cambridge, MA: MIT Press.

Fogel, A. (1993). Developing through relationships: Origins of communication, self and culture. New York: Harvester.

Fowers, B. (2005). Virtue and psychology: Pursuing excellence in ordinary practices.

Washington, DC: American Psychological association.

Fowers, B. (2015). The promise of a flourishing theoretical psychology. Journal of Theoretical \& Philosophical Psychology, 35(3), 145-159.

Friesen, L. , \& Cresswell, J. (2017). Rethinking priming: Insight from James' notions of habits and instincts. New Ideas in Psychology, 46, 17-25.

Gadamer, H. (2008). Philosophical hermeneutics. Los Angeles, CA: University of California.

Gantt, E. , Melling, S. , \& Reber, J. (2012). Mechanisms or metaphors? The emptiness of evolutionary psychological explanations. Theory and Psychology, 22(6), 823-841.

Geertz, C. (1973). The interpretation of cultures. New York: Basic Books.

Gergen, K. (1985). The social constructionist movement in modern psychology. American Psychologist, 40(3), 266-275.

Gergen, K. (1994). Realities and relationships. Cambridge, MA: Harvard University Press. Gergen, K. (1999a). Agency: Social construction and relational action. Theory and Psychology, 9(1), 113-115.

Gergen, K. (1999b). An invitation to social construction. Thousand Oaks, CA: Sage.

Gervais, W. , \& Norenzayan, A. (2012). Analytic thinking promotes disbelief. Science, 336, 493-496.

Greenspan, S. , \& Shanker, S. (2006). The first idea: How symbols, language, and intelligence evolved from our primate ancestors to modern humans. Cambridge, MA: De Capo.

Greenspan, S. , \& Shanker, S. (2007). The developmental pathways leading to pattern recognition, joint attention, language and cognition. New Ideas in Psychology, 25, 128-142. Gregory, J. , \& Barrett, J. (2009). Epistemology and counterintuitiveness: Role and relationship in epidemiology of cultural representations. Journal of Cognition \& Culture, 9, 289-314.

Guthrie, S. (1993). Faces in the clouds: A new theory of religion. New York: Oxford University. Guthrie, S. (2002). Animal animism: Evolutionary roots of religious cognition. In I. Pyysiäinen \& $\mathrm{V}$. Anttonen (Eds.), Current approaches in the cognitive science of religion (pp. 38-67). New York: Continuum.

Hall, D. , Meador, K. , \& Koenig, H. (2008). Measuring religiousness in health research: Review and critique. Journal of Religious Health, 47, 134-163. 
Halonen, J. , Landrum, E. , Buskist, W. , BMcCarthy, M. , Dunn, D. , Rudmann, J. , Freeman , J, Stoloff, M. , Hill, W. , Enns, C. , \& Kaslow, N. (2013). APA guidelines for the undergraduate psychology major - Version 2.0. On-line document prepared by the American Psychological Association Board of Educational Affairs Task Force on Psychology Major Competencies.

Retrieved from www.apa.org/ed/precollege/about/psymajor-guidelines.pdf

Hampson, P. (2005). Cultural psychology and theology: Partners in dialogue. Theology and Science, 3(4), 259-274.

Harré, R. (2002). Cognitive science. Thousand Oaks, CA: Sage.

Hermans, H. , \& Kempen, H. (1993). The dialogical self. Toronto: Academic Press.

Hirschfeld, L. , \& Gellman, S. (1994). Towards a topography of mind: An introduction to domain specificity. In L. Hirschfeld \& S. Gellman (Eds.), Mapping the mind: Domain specificity in cognition and culture (pp. 3-36). Cambridge: Cambridge University.

Hofstede, G. (1980). Culture's consequences: International differences in work-related values. Thousand Oaks, CA: Sage.

Hsu, H. , \& Fogel, A. (2002). Stability and transitions in mother-infant face-to-face communication during the first 6 months: A microhistorical approach. Development Psychology, 39(6), 1061-1082.

James, W. (1956). Will to believe. New York: Dover Publications (original publication 1897)

James, W. (1981). Pragmatism. Indianapolis, IN: Hackett (original publication 1907)

James, W. (1982). The varieties of religious experience. New York: Penguin (original publication 1902)

James, W. (1996). A pluralistic universe. Lincoln: University of Nebraska Press (original publication 1909)

James, W. (1996). Essays in radical empiricism. Lincoln: University of Nebraska Press (original publication 1912)

James, W. (2011). The meaning of truth. New York: Barnes \& Noble Digital Library (original publication 1909)

Kapuscinski, A. , \& Masters, K. (2010). The current status of measures of spirituality: A critical review of scale development. Psychology of Religion \& Spirituality, 2(4), 191-205.

Karasavvidis, I. (2002). Distributed cognition and educational practice. Journal of Interactive Learning Research, 13, 11-29.

Kashima, Y. (2000). Conception of culture and person for psychology. Journal of Cross-Cultural Psychology, 31(1), 14-32.

Kashima, Y. (2016). Culture and psychology in the 21st century: Conceptions of culture and person for psychology revisited. Journal of Cross-Cultural Psychology, 47(1), 4-20.

Keesing, R. (1974). Theories of culture. Annual Review of Anthropology, 3, 73-97.

Keesing, R. (1990). Theories of culture revisited. Canberra Anthropology, 13(2), 46-60.

Keleman, D. (2004). Are children "Intuitive theists?" Reasoning about purpose and design in nature. Psychological Science, 15(5), 296-301.

Keleman, D. , \& Rosset, E. (2009). The human function compunction: Teleological explanation in adults. Cognition, 111, 138-143.

Kitayama, S. , \& Cohen, D. (Eds.). (2007). Handbook of cultural psychology. New York: Guilford Press.

Krakovsky, M. (2012, April 26). Losing your religion: Analytic thinking can undermine belief.

Scientific American. Retrieved from www.scientificamerican.com

Lewis, M. D. (2000). The promise of dynamic systems approaches for an integrated account of human development. Child Development, 71(1), 36-43.

Maturana, H. , \& Varela, F. (1980). Autopoiesis and cognition. Hingham, MA: Reidel Publishing. McCauley, R. N. (2011). Why religion is natural and science is not. New York: Oxford University.

McCauley, R. N. , \& Lawson, E. (2002). Bringing ritual to mind: Psychological foundations of cultural forms. Cambridge: Cambridge University Press.

McConnel, K. , \& Edman, L. (2013). Theological correctness, practiced naturalism, and the intrusion of intuitive concepts. The Society for the Scientific Study of Religion Annual Conference, Boston, MA.

McLean, M. , Cresswell, J. , \& Ashley, C. (2016). Psychologists finding religion: Enhancing cognitive science of religion with cultural psychology. Culture \& Psychology, 22(1), 44-64. 
Meezenbroek, E. , Garssen, B. , van den Berg, M. , van Dierendonck, D. , Visser, A. , \& Schaufeli, W. (2012). Measuring spirituality as a universal experience: A review of spirituality questionnaires. Journal of Religion and Health, 31, 336-354.

Miller, P. (1996). Instantiating culture through discourse practices: Some personal reflections on socialization and how to study it. In R. Jessor , A. Colby , \& R. Shweder (Eds.), Ethnography and human development (pp. 183-204). Chicago: University of Chicago Press.

Murray, M. , \& Goldberg, A. (2009). Evolutionary accounts of religion: Explaining and explaining away. In J. Schloss \& M. Murray (Eds.), The believing primate: Scientific, philosophical and theological reflection on the origins of religion (pp. 100-117). Oxford: Oxford University Press. Neisser, U. (1994). Multiple systems: A new approach to cognitive theory. European Journal of Cognitive Psychology, 6(3), 225-241.

Nietzsche, F. (1964). Nietzsche: An anthology of his works. New York: Washington Square Press.

Noë, A. (2009). Out of our heads: Why you are not your brain and other lessons from the biology of consciousness. New York: Hill \& Wang.

Nussbaum, M. (2016). Not for profit: Why democracy needs the humanities. Princeton, NJ: Princeton University Press.

Oppenheim, D. , Nir, A. , Warren, S. , \& Emde, R. N. (1997). Emotion regulation in mother child narrative co-construction: Associations with children's narratives and adaptation.

Developmental Psychology, 33(2), 284-294.

Paloutzian, R. (1996). Invitation to the psychology of religion (2nd ed.). Toronto: Allyn \& Bacon. Pappas, S. (2012, April 26). Analytic thinking can promote atheism. LiveScience. Retrieved from http://www.livescience.com

Peters, B. (2013). Evolutionary psychology: Neglecting neurobiology in defining the mind. Theory and Psychology, 23(3), 305-322.

Polkinghorne, D. E. (1983). Methodology for the human sciences: Systems of inquiry. Albany: State University of New York Press.

Potter, J. , \& Wetherell, M. (1987). Discourse and social psychology: Beyond attitudes and behaviour. Newbury Park: Sage.

Prinz, J. (2009). Is consciousness embodied? In P. Robbins \& M. Aydede (Eds.), The Cambridge handbook of situated cognition (pp. 419-537). New York: Cambridge University Press.

Proulx, J. (2004). The enactivist theory of cognition and behaviorism: An account of the processes of individual sense making. Proceedings of the 2004 Complexity Science and Research Conference (pp. 115-120).

Pyysiäinen, I. (2002). Introduction: Cognition and culture in the construction of religion. In I. Pyysiäinen \& V. Anttonen (Eds.), Current approaches in the cognitive science of religion (pp. 1-13). New York: Continuum.

Ratner, C. (2006). Cultural psychology: A perspective on psychological functioning and social reform. Mahwah, NJ: Psychology Press.

Reber, J. (2006). Secular psychology: What's the problem? Journal of Psychology and Theology, 34(3), 193-204.

Richardson, F. (2012). On psychology and virtue ethics. Journal of Theoretical and Philosophical Psychology, 32(1), 24-34.

Richardson, R. (2007). Evolutionary psychology as maladapted psychology. Cambridge, MA: MIT Press.

Richerson, P. , \& Newson, L. (2009). Is religion adaptive? Yes, no, neutral. But mostly we don't know. In J. Schloss \& M. Murray (Eds.), The believing primate: Scientific, philosophical and theological reflection on the origins of religion (pp. 100-117). Oxford: Oxford University Press.

Robbins, P. , \& Aydede, M. (2009). A short primer on situated cognition. In P. Robbins \& M. Aydede (Eds.), The Cambridge handbook of situated cognition (pp. 3-10). New York: Cambridge University Press.

Rogoff, B. (2005). The cultural nature of human development. Oxford: Oxford University Press. Rohner, R. P. (1984). Toward a conception of culture for cross-cultural psychology. Journal of Cross-Cultural Psychology, 15(2), 111-138.

Rosaldo, M. (1984). Toward an anthropology of self and feeling. In R. Shweder \& R. LeVine (Eds.), Culture theory: Essays on mind, self, and emotion. New York: Cambridge. 
Said, E. (1996). Representations of the intellectual. New York: Vintage Books.

Saxe, G. (1996).Studying cognitive development in sociocultural context: The development of a practice-based approach. In R. Jessor , A. Colby , \& R. Shweder (Eds.), Ethnography and human development (pp. 275-304). Chicago: University of Chicago Press.

Segall, M. , Lonner, W. , \& Berry, J. (1998). Cross-cultural psychology as a scholarly discipline: On the flowering of culture in behavioural research. American Psychology, 53(10), 1101-1110. Shannon, C. E. , \& Weaver, W. (1949). The mathematical theory of communication. Urbana, IL: University of Illinois Press

Shapiro, L. (2011). Embodied cognition. New York: Routledge.

Shor, I. (1987). Critical teaching and everyday life. Chicago: University of Chicago Press. Shotter, J. , \& Billig, M. (1998). A Bakhtinian psychology: From out of the heads of individuals and into the dialogues between them. In M. Bell \& M. Gardiner (Eds.), Bakhtin and the human sciences: No last words (pp. 13-29). Thousand Oaks, CA: Sage.

Shweder, R. (1991). Thinking through cultures: Expeditions in cultural psychology. Cambridge, MA: Harvard University Press.

Simon, H. (1998). What is an 'explanation' of behavior? In P. Thagard (Ed.), Mind readings: Introductory selections on cognitive science (pp. 1-28). Cambridge, MA: MIT Press.

Slife, B. , \& Reber, J. (2009). Is there a pervasive implicit bias against theism in psychology? Journal of Theoretical and Philosophical Psychology, 29(2), 63-79.

Slife, B. , \& Reber, J. (2012). Conceptualizing religious practices in psychological research: Problems and prospects. Pastoral Psychology, 61, 735-746.

Slife, B. , \& Williams, R. (1995). What's behind the research? Thousand Oaks, CA: Sage. Slone, D. (2004). Theological correctness: Why religious people believe what they shouldn't. New York: Oxford University Press.

Smith, C. (2010). What is a person: Rethinking humanity. Chicago: University of Chicago. Smith, P. , \& Bond, M. (1999). Culture: The neglected concept. In P. Smith \& M. Bond (Eds.), Social psychology across cultures (pp. 38-68). Harlow: Prentice Hall.

Spelke, E. S. , Breinlinger, K. , Macomber, J. , \& Jacobson, K. (1992). Origins of Knowledge. Psychological Review, 99(4), 605-632.

Spelke, E. S. , \& Kinzler, K. (2007). Core knowledge. Developmental Science, 10(1), 89-96. Sperber, D. (1994). The modularity of thought and the epidemiology of representations. In L. Hirschfeld \& S. Gellman (Eds.), Mapping the mind: Domain specificity in cognition and culture (pp. 39-67). Cambridge: Cambridge University.

Sperber, D. (1996). Explaining culture: A naturalistic approach. Malden, MA: Blackwell.

Sperber, D. , \& Hirschfeld, L. (2004). The cognitive foundations of stability and diversity. Trends in Cognitive Science, 8(1), 40-46.

Stam, H. (2015a). The historical boundedness of psychological knowledge and the ethics of shared understandings. Journal of Theoretical \& Philosophical Psychology, 35(2), 117-127.

Stam, H. (2015b). Indeterminate functionalism and possessive individualism. In J. Cresswell , A. Haye , A. Larraín , M. Morgan , \& G. Sullivan (Eds.), Dialogue and debate in the making of theoretical psychology (pp. 385-403). Concord, ON: Captus.

Sugarman, J. (2015). Neoliberalism and psychological ethics. Journal of Theoretical \& Philosophical Psychology, 35(2), 105-116.

Tallis, R. (2011). Aping mankind: Nueromania, darwinitis, and the misrepresentation of humanity. Durham: Acumen.

Taylor, C. (1989). Sources of the self: The making of the modern identity. Cambridge, MA: Harvard University Press.

Taylor, C. (1999). Human agency and language: Philosophical papers volume 1. Cambridge: Cambridge University Press.

ten Have, P. (2002). Doing conversation analysis: A practical guide. Thousand Oaks, CA: Sage. Teo, T. (2008). From speculation to epistemological violence in psychology: A criticalhermeneutic reconstruction. Theory \& Psychology, 18(1), 47-67.

Teo, T. (2015). Are psychological "ethics codes" morally oblique? Journal of Theoretical \& Philosophical Psychology, 35(2), 78-89.

Thagard, P. (2005). Mind: Introduction to cognitive science. Cambridge, MA: MIT Press. Thelen, E. (2005). Dynamic systems theory and the complexity of change. Psychoanalytic Dialogues, 15(2), 255-283. 
Thelen, E. , \& Smith, L. (1996). A dynamic systems approach to the development of cognition and action. Cambridge, MA: MIT Press.

Thompson, E. (2007). Mind in life: Biology, phenomenology, and the sciences of mind.

Cambridge, MA: Harvard University.

Tooby, J. , \& Cosmides, L. (1992). The psychological foundations of culture. In J. Barkow, L.

Cosmides , \& J. Tooby (Eds.), The adapted mind: Evolutionary psychology and the generation of culture (pp. 19-136). New York: Oxford University.

Underwood, L. (2011). The daily spiritual experience scale: Overview and results. Religions, 2, 29-50.

Underwood, L. , \& Teresi, J. (2002). The daily spiritual experience scale: Development, theoretical description, reliability, exploratory factor analysis, and preliminary construct validity using health-related data. Annals of Behavioral Medicine, 24(1), 22-33.

Valinser, J. (2012). The Oxford handbook of cultural psychology. New York: Oxford University. van Orden, G. C. , Holden, J. G. , \& Turvey, M. T. (2003). Self-organization of cognitive performance. Journal of Experimental Psychology: General, 132(3), 331-350.

Varela, F. , Thompson, E. , \& Rosch, E. (1992). The embodied mind: Cognitive science and human experience. Cambridge, MA: The MIT Press.

Vattimo, G. (2002). After Christianity. New York: Columbia University.

Vattimo, G. (2011). A farewell to truth. New York: Columbia University.

Walsh, R. (2015). Bending the arc of North American psychologists' moral universe towards communicative ethics and social justice. Journal of Theoretical \& Philosophical Psychology, 35(2), 90-102.

Walsh, R. , \& Gokani, R. (2014). The personal and political economy of psychologists' desires for social justice. Journal of Theoretical \& Philosophical Psychology, 34(1), 41-55.

Wertsch, J. (1985). Vygotsky and the social formation of mind. Cambridge, MA: Harvard University Press.

Wertsch, J. (1991). Voices of the mind: A sociocultural approach to mediated action. London: Harvester Wheatsheaf.

Whitehouse, H. (2004). Modes of religiosity: A cognitive theory of religious transmission. New York: AltaMira Press.

Xygalatas, D. (2012). The burning saints: Cognition and culture in fire-walking rituals of the Anastenaria. Sheffield: Equinox.

Yonker, J. , Edman, L. , Cresswell, J. , \& Barrett, J. (2016). Primed analytic thought and religiosity: The importance of individual characteristics. Journal of Religion and Spirituality. Online pre-print, doi:10.1037/rel0000095.

Žižec, S. (2008). The plague of fantasies. New York: Verso. 